http://kitaibelia.unideb.hu/

ISSN 2064-4507 (Online) • ISSN 1219-9672 (Print)

(C) 2017, Department of Botany, University of Debrecen, Hungary

22 (1): 114-121.; 2017

DOI: $10.17542 /$ kit.22.114

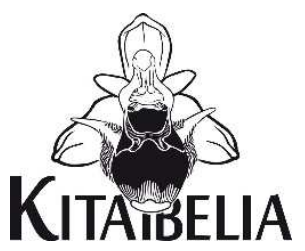

\title{
Néhány florisztikai adat Kötcse környékéről II. (Dél-Dunántúl, Nyugat-Külső-Somogy)
}

\author{
NAGY Timea \\ Pannon Egyetem, Georgikon Kar, Növénytudományi és Biotechnológiai Tanszék, H-8360 Keszthely, Festetics u. 7. \\ tima.nagy@gmail.com

\section{Some floristic data from surroundings of Kötcse II. (West Outer Somogy, South Transdanubia, Hungary)}

\begin{abstract}
Floristic data of 73 species from NE part of West Outer Somogy are provided in the paper. Most of them were collected in 2016. The paper contains distribution data of species, which have not been detected in Outer Somogy so far (e.g. Peucedanum arenarium), and new occurrences of rare or sporadic taxa (e.g. Menyanthes trifoliata, Veronica scardica), as well as subspontaneous occurrences of cultivated species (e.g. Narcissus poëticus, Helleborus purpurascens) are provided.
\end{abstract}

Keywords: flora of Hungary, Somogy county, rare species, vascular plants

Összefoglalás - Munkámban 73 faj, nagyrészt 2016-ban gyűjtött előfordulási adatát közlöm NyugatKülső-Somogy északkeleti szegletéből. A kézirat Külső-Somogyból eddig nem ismert fajok (például Peucedanum arenarium) előfordulási adatait, a Dél-Dunántúlon vagy az egész országban ritkának vagy szórványosnak tekinthető fajok (például Menyanthes trifoliata, Veronica scardica) újabb lelőhelyeit, valamint néhány kultúrszökevény (például Narcissus poëticus, Helleborus purpurascens) előfordulási adatait tartalmazza.

Kulcsszavak: Magyarország flórája, Somogy megye, ritka fajok, hajtásos növények

\section{Bevezetés}

Külső-Somogy a florisztikai szempontból kevéssé feltárt kistájaink egyike. A terület növényvilágát részletesen bemutató mű HoRVÁt (1942) óta nem jelent meg. Az utóbbi időben PINKE et al. (2006), KIRÁLY (2007) és ROZNER et al. (2011) közöltek florisztikai adatokat ebből a tájból, valamint KIRÁLY (1998), LÁJER (2003), Z. HORVÁtH (2007) és KovÁCS (2014) munkája részben érinti ezt a környéket.

Munkámban 73 faj előfordulási adatát közlöm Nyugat-Külső-Somogy (MAROSI \& SOMOGYI 1990) 8 településéről (Balatonszárszó, Kereki, Kötcse, Kőröshegy, Nagycsepely, Somogytúr, Szólád, Teleki) (1. ábra). Az adatok nagyobb része 2016-ból, néhány 2015-ből származik. Ritka, védett fajok mellett ültetésből, kivadulásból származó adat is megjelenik a dolgozatban. A felsorolt fajok sorszámozása és nómenklatúrája KIRÁLY (2009) munkáját követi. A határozások során szintén KIRÁLY (2009) munkáját használtam. A dúlőnevek esetében a III. katonai felmérés (1869-1887) [1] térképszelvényeit és az 1:10 000-es méretarányú EOTR topográfiai térképet vettem figyelembe. A flóratérképezési kvadrátok azonosítói (NiKLFELD 1971 alapján) mellett a herbáriumi példányok meglétét is jelzem $(\mathrm{H})$. A preparátumok a Pannon Egyetem, Georgikon Kar, Növénytudományi és Biotechnológiai Tanszékének herbáriumában kerültek elhelyezésre. 


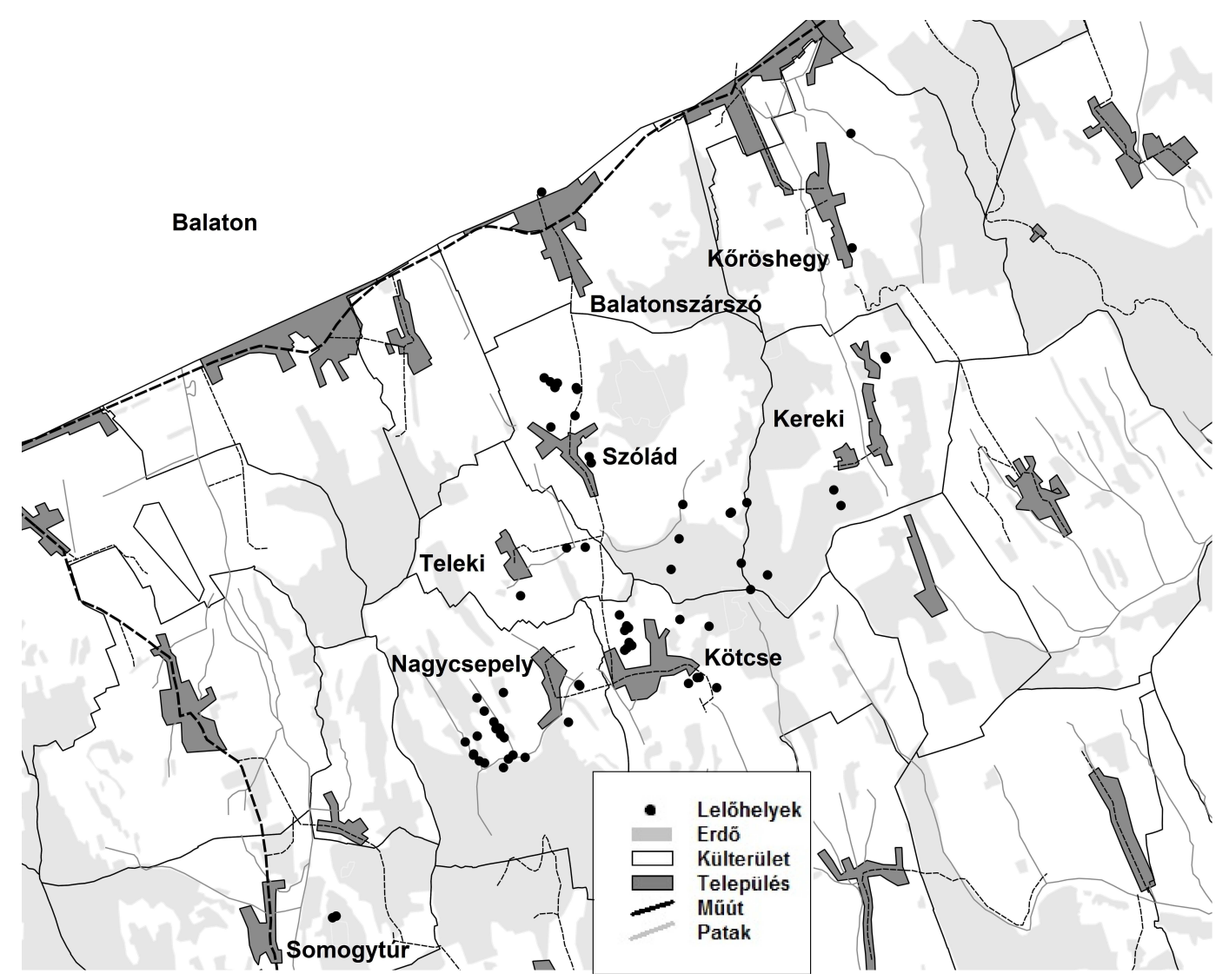

1. ábra. A vizsgált terület térképvázlata

Fig. 1. Map of the study area (localities are indicated by dots)

\section{Enumeráció}

40. Asplenium ruta-muraria L. - Kereki: Fejérkővár, várfal [9273.1]. - Archív adata ismert Kerekiből, de HoRvÁT (1942) pontos helymegjelölést nem ad meg flóraművében, ezen kívül legközelebbi előfordulása Kaposvárról ismert (Z. HoRVÁTH 2007).

146. Urtica urens L. - Kötcse: Újhegy, belterület, disznóól környékén [9273.1] (H). - A vizsgált területről korábbi adatát nem találtam. BARTHA et al. (2015) térképe a DélDunántúlon szórványosnak jelöli.

151. Thesium ramosum Hayne - Szólád: a Köpü-Horog gyep-fragmentumaiban [9273.1] (H). - A környékről legközelebbi előfordulása Balatonlelléről ismert [9272.1] (BARTHA et al. 2015, Lájer Konrád 2004-es flóratérképezési adata).

153. Thesium linophyllon L. - Szólád: a Köpü-Horog gyep-fragmentumaiban és az ótemetőben [9273.1] (H). Kereki: temető feletti löszgyep [9173.4]. - A környékről ismert néhány előfordulása: Buzsák (HoRvÁt 1942), Látrány (LÁJER 2003), Nagyberek (LÁJER 2007).

289. Minuartia glaucina Dvořáková - Nagycsepely: temető mögötti gyep [9273.1] (H). - A vizsgált területről korábbi adatát nem találtam, sőt, BARTHA et al. (2015) térképe alig jelöli előfordulását a Dél-Dunántúlon.

339.2. Silene otites (L.) Wibel subsp. hungarica Wrigley - Szólád: a Köpü-Horog gyepfragmentumaiban [9273.1] (H). - Méretei (virágzat ágai, tőlevelek szélessége, kocsányok 
hossza) és magjának bibircses felszíne alapján (vö. KIRÁLY 2009) az egyes szerzők által faji rangon kezelt taxon (vö. NiKETIĆ et al. 2007) egyértelmúen azonosítható. JÁvORKA (1926) alfaj megjelölése nélkül Siófokról jelzi.

386. Helleborus purpurascens Waldst. et Kit. - Kötcse: Sárközy-kert, romos, elhagyott nyaraló területén 3, minden bizonnyal egykor odaültetett példány [9273.1] (H).

394. Isopyrum thalictroides L. - Nagycsepely: Vadas erdő [9272.4] (H). - A vizsgált területről és annak környékéről korábbi adatát nem találtam. Legközelebbi előfordulása: Tamási (HoRvÁT 1942). Z. HoRvÁTH (2007) szerint a Zselic nyirkos erdőiben ritka.

414. Pulsatilla grandis Wender. - Somogytúr: Csúcs-hegy [9272.4] (H). - Legközelebbi adata Balatonszárszóról és Siófokról (RozNER et al. 2011) ismert.

416. Pulsatilla nigricans Störck - Szólád: az ótemető szélén, 1 tő [9273.1] (H). Köröshegy: Tekenyős, körülbelül 10 tő [9173.3] (H). Kereki: temető melletti gyep, több 10 tő [9173.4] (H). - A szóládi ótemető gyepje erősen fel van avarosodva és a bálványfa terjed rajta. A helyiek saját elmondása alapján tudjuk, hogy a $P$. nigricans és az Adonis vernalis töveit kiássák és kertjeikbe ültetik. A fekete kökörcsin a vizsgált terület további néhány településéről ismert: Látrány (LÁJER 2003, ROZNER et al. 2011), Balatonszárszó, Balatonendréd, Somogytúr (RozNER et al. 2011).

424. Adonis vernalis L. - Szólád: ótemető, 20-30 tő [9273.1] (H). - A település Nezde kültelekéről ismert (NAGY 2015). A lelőhelytől keletre számos településen (Balatonszárszó, Balatonendréd, Kapoly, Kőröshegy, Ságvár, Siófok, Szántód, Tab, Zamárdi) megtalálható, nem ritka a környéken (HoRváT 1942, Z. HORVÁTH 2007, ROZNER et al. 2011).

437. Ranunculus illyricus L. - Szólád: a temető bejáratánál tömeges és a temető nagy részén foltokban gyakori [9273.1] (H). Teleki: temető [9272.2]. Köröshegy: temető [9173.3] (H). Kereki: temető [9173.4] (H). - A környékről kevés és főleg régi adata ismert: Balatonboglár (Borbás 1900), Buzsák (HoRvÁt 1942), Látrány (LÁjER 2003). További lelőhelyeinek előkerülése várható.

462. Thalictrum minus L. - Szólád: a Köpü-Horog gyep-fragmentumaiban és az ótemetőben [9273.1]. - A vizsgált környékre vonatkozólag adatát nem találtam, de BARTHA et al. (2015) térképe az általam ismertetett lelőhelyek szomszédos flóratérképezési kvadrátjából jelzi, ugyanakkor kevés előfordulási adatát szemlélteti Somogy megyében.

471. Mahonia aquifolium agg. - Kötcse: a Vásártéri út mentén, kivadulások [9273.1]. Valószínúleg az egykor itt állt kúria kertjében ültették.

488. Corydalis solida L. - Szólád: Nezde [9273.1]. - A vizsgált területhez legközelebbi előfordulása Szőlősgyörökről ismert [9272.3] (BARTHA et al. 2015, Lájer Konrád 2004-es flóratérképezési adata).

498. Sisymbrium orientale L. - Szólád: a Köpü-Horog gyep-fragmentumaiban [9273.1] (H). KOvÁCS \& PRISZTER (1957) a Nagyberekből, SZALÓKI \& BóDIS (2004) a Szemesi-berekből jelzi.

547. Arabis glabra (L.) Bernh. - Nagycsepely: a Petőfi S. utca végén lévő halastó környékén 10 példány [9272.4] (H). - Legközelebb HoRvÁt (1942) Szántód-Zamárdi és Lengyeltóti területéről említi.

552. Arabis hirsuta (L.) Scop. - Szólád: a Köpü-Horog gyep-fragmentumaiban [9273.1] (H). Kötcse: Fáncsi-hegy, szőlőparlag [9273.1]. Nagycsepely: ótemető [9273.3]. - Legközelebbi előfordulásai Buzsákról (HoRvÁT 1942) és Simontornyáról (HoRvÁT 1942) ismertek.

643. Sedum acre L. - Szólád: Nezde, földút szélén [9273.1]. - Valószínűsítem, hogy előfordul még több ponton ezen a környéken. Legközelebb Látrányból ismert (LájER 2003). Z. HoRVÁTH (2007) a Zselic számos településérôl említi.

647. Saxifraga tridactylites L. - Balatonszárszó: vasútállomás [9173.3] (H). - A vasútvonal mentén nagy valószínűséggel több településen is megtalálható. HoRvÁT (1942) Mernye és Gamás közötti előfordulásáról ír. 
654. Ribes uva-crispa L. - Szólád: Alsó-Nezde, földút mentén, az Almán-tető közelében [9273.1]. - Legközelebbi előfordulása Ságvárról ismert [9174.4] (BARTHA et al. 2015, Barina Zoltán 2003-as flóratérképezési adata). KIRÁLY (2007) dél-külső-somogyi településekről (Fonó, Kapospula, Magyaratád) jelzi meglétét.

678. Rosa spinosissima L. - Szólád: Majori-dűlő, útszél [9273.1] (H). - Legközelebb Tamásiból ismert egy archív adata (GOMBOCZ \& HoRvÁT 1941), a Dél-Dunántúlon ritkának mondható (BARTHA et al. 2015).

761. Sorbus domestica L. - Nagycsepely: Pácsmánd, 3 idős fa [9272.4]. Szólád: Köpü-Horog, 1 példány [9173.3]. - Szólád-Nezdén ismert (NAGY 2015), HoRVÁT (1942) Tamásiból említi.

840. Chamaecytisus supinus (L.) Link - Kötcse: Fáncsi-hegy, szőlőparlag, 1 példány [9273.1] (H). - Karádról és Szántódról ismertek archív adatai (HoRVÁT 1942). A szomszédos SzóládNezdéről ismert (NAGY 2015).

842. Chamaecytisus austriacus (L.) Link - Nagycsepely: Pácsmánd [9272.4] (H). Szólád: Balatonszárszó felé vezető út mezsgyéjén [9273.1] (H). Somogytúr: Csúcs-hegy [9272.4] (H). Teleki: temető fölötti löszgyepek [9272.2] (H). - Utóbbi lelőhelyen Ch. supinus-szal alkotott hibridje is előfordul, melyre a csésze markánsan elálló szőrözöttsége, a virágzat elhelyezkedése (szár oldalán) és a vékony, lekopaszodó szőrcsíkkal rendelkező vitorla utal (Pifkó D. ex lit.). A Ch. austriacus-nak Balatonszemesről ismert egy archív adata (BoRBÁS 1900), a nagycsepelyi Hársas-erdő melletti löszgyepmaradványban előfordul (NAGY 2015).

861. Colutea arborescens L. - Kötcse: az Arany J. utca végén, szőlőparlagon, néhány tő [9273.1]; Fáncsi-hegy, szőlőparlag, 6 példány [9273.1]. Szólád: a Köpü-Horog gyepfragmentumaiban [9273.1] (H). - Karádról, Kerekiből és Ságvárról ismert archív adata (HoRvÁT 1942).

891. Vicia pisiformis L. - Kötcse: Fáncsi-hegy, szőlőparlag 10 példány [9273.1]. - HoRVÁT (1942) két környékbeli előfordulásáról ír: Kereki és Törökkoppány.

897. Vicia tenuifolia Roth - Szólád: Nezde [9273.1] (H). - A közeli Balatonendrédről származik egy archív adata (MÁGOCSY-DIETZ 1914), távolabbi lelőhelyéről HoRVÁt (1942) tesz említést: Törökkoppány és Koppányszántó között.

913. Lathyrus sphaericus Retz. - Köröshegy: a temető nyugati kitettségű oldalában, rendszeresen kaszált, száraz gyepben néhány tő [9173.3] (H). - Környékbeli előfordulásáról nem találtam adatot, BARTHA et al. (2015) térképén a Tihanyi-félszigetről jelzik. A már említett domboldalban a nagyfejü csajkó (Lethrus apterus Laxmann) egy jelentős populációja is él.

933. Ononis pusilla L. - Szólád: a Köpü-Horog gyep-fragmentumaiban, néhány tő [9173.3] (H). - KIRÁLY (2007) a közeli Szántód településen észlelte.

953. Medicago minima (L.) L. - Szólád: a Köpü-Horog gyep-fragmentumaiban [9273.1] (H). - Adata két környékbeli településről ismert: Látrány (LÁJER 2003, PINKE et al. 2006) és Balatonlelle (PINKE et al. 2006).

1031. Linum tenuifolium L. - Somogytúr: Csúcs-hegy [9272.4] (H). - Archív környékbeli adata Tamásiból származik (GoMBOCZ \& HoRvÁT 1941). Legközelebb Balatonszárszóról (ROZNER et al. 2011) ismert.

1032. Linum hirsutum L. - Szólád: a Köpü-Horog gyep-fragmentumaiban tömeges [9273.1, 9173.3] (H). Nagycsepely: Pácsmánd, gyakori [9272.4]. Somogytúr: Csúcs-hegy [9272.4] (H). - A környék két településéről jelezték: Siófok (BoRBÁs 1900) és Balatonszárszó (ROZNER et al. 2011).

1052. Euphorbia epithymoides L. - Szólád: Nezde [9273.1] (H). - Legközelebbi archív adatait Tamásiból (JÁVORKA 1926), Regölyből és Koppányszántóról találtam (HoRVÁT 1942).

1135. Thymelaea passerina (L.) Coss. et Germ. - Nagycsepely: Nádasdi-rét [9272.4] (H). Somogytúr: Csúcs-hegy [9272.4] (H). - Archív adata Balatonőszödről származik (MÁGOCSYDiETZ 1914), Kötcse és Pusztaszemes közötti előfordulásáról PINKE et al. (2006) írnak. 
1272. Seseli osseum Crantz em. Simonk. - Somogytúr: Csúcs-hegy [9272.4] (H). Legközelebbi adatai Siófokról [9174.1] (BARTHA et al. 2015, Barina Zoltán 2003-as flóratérképezési adata) és Balatonendrédről [9173.4] (BARTHA et al. 2015, Bódis Judit 2004-es flóratérképezési adata) ismertek.

1310. Peucedanum arenarium Waldst. et Kit. - Somogytúr: Csúcs-hegy [9272.4] (H). - A környékről előfordulását nem találtam. Legközelebb Belső-Somogyból: Nagybajomból, Szentáról és Darányból ismertek állományai (BoRHIDI 1957-1958).

1315. Peucedanum oreoselinum (L.) Moench - Nagycsepely: ótemető [9273.3]. Környékbeli előfordulásai Lengyeltótiból, Buzsákról (HoRVÁT 1942), valamint Látrányból (LÁJER 2003) ismertek.

1320. Tordylium maximum L. - Szólád: a Köpü-Horog gyep-fragmentumaiban [9173.3] (H). - Legközelebbi előfordulási pontjai Fiadról, Somogydöröcskéről (PINKE et al. 2006) és Kötcséről (NAGY 2015) ismertek.

1338. Monotropa hypopitys L. - Kereki: Bellák [9273.1] (H). - A vizsgált terület közvetlen környékéről nem találtam korábbi adatát. Külső-Somogyból KEVEY (1985) említi először, Gyulajról. Az Észak-Zselicben több településen is ismert: Kaposvár, Bőszénfa, Szenna, Gálosfa (Z. HoRvÁth 2007).

1390. Menyanthes trifoliata L. - Nagycsepely: tömeges a Nádasdi-rét nádasában; virágzó példányt 2016-ban nem találtam [9272.4] (H). - A lelőhelytől légvonalban mintegy 6 km-re található legközelebbi, néhány tíz töves állománya Látrányban (RozNER et al. 2011).

1409. Cuscuta europaea L. - Nagycsepely: Vadas erdő előtti fahídnál [9272.4] (H). Legközelebbi előfordulása Somogybabodról [9372.2] (BARTHA et al. 2015, Csiky János és Csikyné Radnai Éva 2004-es flóratérképezési adata) ismert.

1420. Echium italicum L. - Nagycsepely: a vadászház környékén, földút szélén 10 tő [9272.4]. - Közeli előfordulásai: Balatonendréd (MÁGOCSY-DiETZ 1914), Lengyeltóti, Kereki, Balatonkiliti (HoRvÁt 1942), Kötcse (NAGY 2015).

1618. Cymbalaria muralis G. Gaertn., B. Mey. et Scherb. - Balatonszárszó: József Attila múzeum előtti betonhídon [9173.3] (H). - Külső-Somogyból adatát nem találtam. BARTHA et al. (2015) térképe a Dél-Dunántúlon ritkának jelzi.

1632. Veronica scardica Griseb. - Nagycsepely: a Nádasdi-rét nádasában [9272.4] (H). BARTHA et al. (2015) térképe országosan igen ritkának jelöli, de archív adatai ismertek Kötcséről (Mágocsy-Dietz S., 1916.VIII.11., DE-soo-28317, BP-546021), Szőlősgyörökről (JÁVORKA 1936) és Kisberényből (Boros Á., 1933.IX.16., BP-456358).

1662. Melampyrum barbatum Waldst. et Kit. - Szólád: a Köpü-Horog gyepfragmentumaiban [9273.1] (H). - A lelőhely környékéről nem találtam irodalmi adatát, távolabbi lelőhelyei közé tartozik Mezőkomárom, Tamási (GomBocz \& HoRvÁT 1941) és Kaposvár (Z. HoRVÁTH 2007).

1715. Sherardia arvensis L. - Szólád: a Köpü-Horog gyep-fragmentumaiban [9273.1] (H). A közvetlen környékről nem ismert, legközelebbi előfordulásai Simontornyához (PILLICH 1927), Ozorához és Várdához (LENGYEL 1929) köthetők.

1742. Galium schultesii Vest - Kereki: Bellák [9273.1] (H). - Legközelebbi előfordulási pontjai HoRvÁT (1942) flóraműve alapján Szántód, Zamárdi és Ságvár községben találhatóak.

1862. Carpesium cernuum L. - Szólád: Nezde [9273.1]. Kereki: Bellák, cseres-tölgyesben 1 tő, [9273.1] (H). - MÁGOCSY-DIETZ (1914) szerint a szóládi erdőkben, helyenként elég gyakori. További előfordulása Somogyszilből ismert (BoRos 1936).

1965. Echinops sphaerocephalus L. - Szólád: a Köpü-Horog gyep-fragmentumaiban [9273.1] (H). - Archív adatai ismertek Balatonboglárról (BoRBÁs 1900), Lengyeltótiból és Regölyből (HoRvÁt 1942). Legközelebbi adata a Szemesi-berekből (SzALÓKI \& BóDIS 2004) származik. 
1971. Jurinea mollis (L.) Rchb. - Somogytúr: Csúcs-hegy [9272.4]. - A környékről, Szóládról és Balatonszárszóról ismertek adatai (RozNER et al. 2011).

1988. Cirsium rivulare (Jacq.) All. - Nagycsepely: Bárány-rét, 2016-ban 3 virágzó példány és több vegetatív tő [9272.4] (H); Nádasdi-rét [9272.4]. - Archív adata Buzsákról ismert (HORVÁT 1942). A közeli Látrányból LÁJER (2003) és ROZNER et al. (2011) is közlik.

2010. Centaurea stoebe L. - Szólád: a Köpü-Horog gyep-fragmentumaiban [9273.1] (H). Előfordulási adatát nem találtam a környékről. BARTHA et al. (2015) néhány ponttal jelöli dél-dunántúli előfordulását.

2037. Sonchus palustris L. - Nagycsepely: a halastó közelében, patakmederben, 1 tő [9272.4]; Nádasdi-rét, 30 tő [9272.4] (H). - Környékbeli előfordulásai: Lellei-Bozót, Szemesi-berek (SzALóKI \& BóDIS 2004), Hács, Látrány, Somogytúr, Visz, (RozNER et al. 2011), Kötcse, Teleki (NAGY 2015).

2223. Gagea lutea (L.) Ker Gawl. - Szólád: Nezde, Kátyói-völgy, zsilip [9273.1]. - Adatát nem találtam a környékről, BARTHA et al. (2015) térképe is igen ritkának jelzi ebben a tájban.

2244. Narcissus poëticus L. - Kereki: Katona-vár, letermelt erdő területén, tömeges [9272.1]. - Valószínúleg a II. világháborúban lerombolt vadászkastély kertjének maradványa.

2246. Tamus communis L. - Kötcse: ültetett erdeifenyvesben 1 tő [9273.1]. - A környéken, több helyen is ismert: Szőlősgyörök (BoRos 1924), Nagyberek (LÁJER 2007), Gamás, Hács, Kisberény, Somogytúr (RozNER et al. 2011).

2260. Iris variegata L. - Szólád: ótemető [9273.1]. Nagycsepely: ótemető [9273.3]. - Mindkét ótemető bővelkedik ritkább xero-mezofil gyepi fajokban, így valószínű, hogy az I. variegata sem betelepítés eredetű, hanem természetes tagja a növényzetnek. Legközelebb Kapolyról, Fonyódról és Tabról ismert (Z. HoRVÁtH 2007).

2322. Vulpia myuros (L.) C.C. Gmel. - Szólád: Alsó-Nezde és a Páskum között, földút mentén [9273.1]. - Legközelebbi adata a Nagyberekből ismert (LÁjER 2007).

2346. Catabrosa aquatica (L.) P. Beauv. - Nagycsepely: a Petőfi S. utca végén, a halastó környékén, patakmederben [9272.4] (H). - Legközelebbi dél-külső-somogyi előfordulásai: Kapospula, Kisgyalán, Nak, Somogyszil (KIRÁLY 2007). KIRÁLY (2007) szerint a löszvölgyekben kialakuló forrásos helyek jellemző növénye, felbukkanása még számos helyen várható.

2477. Stipa pennata L. - Kötcse: a Fáncsi-hegyen, meredek, regenerálódó szőlőparlagon [9273.1]. Nagycsepely: a településtől nyugati irányban 1 km-re regenerálódó szőlőparlagon, pár négyzetméter kiterjedésű foltban [9272.4] (H). - Régi adatai Simontornyáról (PILLICH 1927) és Tamásiból (HoRvÁT 1942) ismertek.

2527. Arum orientale M. Bieb. - Kötcse: a Sárközy-kertben gyakori [9273.1]. - Legközelebbi települések, melyeken előfordul: Kereki és Ságvár (KIRÁLY 2007).

2596. Carex elongata L. - Nagycsepely: a Petőfi S. utca végén lévő halastó környékén, patakmederben [9272.4] (H). - A környéken adatát nem találtam, BARTHA et al. (2015) térképe Belső-Somogyban gyakorinak mutatja.

2603. Carex paniculata L. - Nagycsepely: a Nádasdi-réten elterülő nádasban [9272.4] (H). Legközelebbi adatait LÁJER (2003) és RoZNER et al. (2011) munkájában találtam: Látrány, Táska. Ugyanakkor BARTHA et al. (2015) térképén az általam is említett flóratérképezési kvadrátban előfordulása jelölve van.

2611. Carex acuta L. - Teleki: Büdös-gáti-víz mentén [9273.1] (H). - Bár országosan nem ritka, a környékről nem találtam adatát. BARTHA et al. (2015) térképén legközelebbi pontjai a Kapos mentén találhatók.

2613. Carex buekii Wimm. - Teleki: Büdös-gáti-víz mentén [9273.1] (H). - Bár az állomány vegetatív, a legalsó tőlevelek lemezének hiánya, a hüvelyek feketésbarna ill. élénkbíboros színe és határozottan rostokra foszló éle egyértelműen a $C$. buekii-re utal (vö. FELFÖLDY 2002). Vegetatív állományok Zalában is gyakran előfordulnak (Óvári M. ex verb.). 
Környékbeli adatát nem találtam. Legközelebb Nyirádról, az Őrségből és a Dráva-vidékről ismert (FELFÖLDY 2002).

2641. Carex vesicaria L. - Nagycsepely: a Petőfi S. utca végén lévő halastó környékén [9272.4] (H). - A környékről adatát nem találtam. BARTHA et al. (2015) térképén legközelebbi előfordulásai Belső-Somogyból ismertek.

2647. Carex michelii Host - Szólád: ótemető [9273.1] (H). Kereki: temető fölötti löszgyepben [9173.4]. Szólád: Nezde [9273.1] (H). - Legközelebbi archív adatai Tamásiból (HoRvát 1942) és Pálfáról (HoRvát 1942) származnak.

2693. Dactylorhiza incarnata (L.) Soó - Nagycsepely: Bárány-rét, 2016-ban 1 virágzó példány [9272.4]. - A környékről ismert adatai: Látrány (LÁJER 2003, ROZNER et al. 2011), Kőröshegy, Ordacsehi (RozNER et al. 2011).

2700. Orchis morio L. - Nagycsepely: temető [9273.3]. - Legközelebbi ismert adatai: Balatonboglár (BoRBÁs 1900), Nagyberek (LÁJER 2007), Tab, Kapoly, Fonyód (Z. HoRváTH 2007), Látrány, Ordacsehi, Lengyeltóti (RozNER et al. 2011), Pusztaszemes, Balatonendréd (CSÁBI et al. 2015).

2702. Orchis tridentata Scop. - Kötcse: Fáncsi-hegy, szőlőparlag, 2016-ban 2 virágzó példány [9273.1]. Somogytúr: Csúcs-hegy [9272.4] (H). Köröshegy: temető, 1 virágzó példány [9173.3]. - Környékbeli előfordulásai: Szólád, Ságvár (RozNer et al. 2011), Visz, Kereki, Siófok-Töreki (CSÁBI et al. 2015).

2704. Orchis purpurea Huds. - Kötcse: Vásártéri út, cserjés, 1 példány [9273.1]; Fáncsi-hegy, cserjés, 3 virágzó és 2 vegetatív tő [9273.1]. - Archív adata Kerekiből ismert (HoRvát 1942). A környéken (Balatonszárszó, Balatonendréd, Karád, Pusztaszemes, Ságvár, Sérsekszőlős, Siófok-Töreki, Szántód, Szólád, Szőlősgyörök, Zamárdi) nem ritka (RozNER et al. 2011, CSÁBI et al. 2015, NAGY 2015).

2705. Orchis militaris L. - Kötcse: Fáncsi-hegy, szőlőparlag, 1 virágzó példány [9273.1]. - A közelben ismert előfordulásai: Balatonmáriafürdő (Soó \& BoRSOS 1957, Kovács \& PRISZTER 1957), Látrány (LÁJER 2003), Tab, Kapoly (Z. HORVÁTH 2007), Lengyeltóti, Ordacsehi, (ROZNER et al. 2011).

\section{Köszönetnyilvánítás}

Szeretném megköszönni Pifkó Dánielnek a Chamaecytisus-ok határozásában nyújtott segítségét, valamint Valent Sándornak, hogy felhívta figyelmemet a somogytúri Csúcs-hegyen található, több ritka és védett növénynek élőhelyet nyújtó területre. Köszönöm Takács Attilának, hogy csatlakozott a terepbejárásokhoz és észrevételeivel hozzájárult az adatsor gyarapodásához. Köszönöm Juhász Magdolna és Schmidt Dávid lektori munkáját, valamint Schmidt Dávidnak a pontos flóratérképezési adatok kigyüjtését.

\section{Irodalom}

Bartha D., Király G., Schmidt D., Tiborcz V., Barina Z., Csiky J., JakAB G., LeSku B., SchmotZer A., VidÉKi R., Vојтко́ A. \& ZóLYomi Sz. (szerk.) (2015): Magyarország edényes növényfajainak elterjedési atlasza. Nyugat-magyarországi Egyetem Kiadó, Sopron, 329 pp.

Borbás V. (1900): A Balaton flórája. A Balaton tavának és partmellékének növényföldrajza és edényes növényzete. - Magyar Földrajzi Társaság, Budapest, 431 pp.

Borhidi A. (1957-1958): Adatok Belső-Somogy flórájához. - Botanikai Közlemények 47: 107-108.

Boros Á. (1924): A drávabalparti síkság flórájának alapvonásai, különös tekintettel a lápokra. - Magyar Botanikai Lapok 23: 1-61.

Boros Á. (1936): Adatok Somogy vármegye flórájának ismeretéhez. - Vasi Szemle 3: 79-86.

CSÁBi M., CSirmaz K., Gregorits J., HasZonits Gy., Hernádi L., Kiticsics A., LuKÁcs R., MaKÁdi S., MARTon J., MolnáR V. A., NAGY T., PÁnCZÉl M., RAKSÁNYI Zs., ResZleR G. \& TAKÁCS A. (2015): Kiegészítések a Magyarország orchideáinak atlasza elterjedési adataihoz. - Kitaibelia 20: 170-172. 
FELFÖLDY L. (2002): Sás-határozó. - Kitaibelia 7: 43.

Gombocz E. \& HoRvát A. O. (1941): Kitaibel Pál botanikus naplófeljegyzései tolnamegyei útjáról 1799, 1808. - In: HoluB J. (szerk.), Tolna vármegye múltjából 6. Egyetemi Könyvkiadó, Pécs, 24 pp.

HoRvÁt A. O. (1942): Külsősomogy és környékének növényzete. - Borbásia 6: 1-70.

JÁvorka S. (1926-1936): Kitaibel herbáriuma I-V. - Annales historico-naturales Musei nationalis hungarici 24: 432., 585., 30: 108-109.

KEVEY B. (1985): Adatok Magyarország flórájának és vegetációjának ismeretéhez III. - Botanikai Közlemények 72: 155-158.

KIRÁLY G. (1998): Adatok a Délkelet-Dunántúl flórájához. - Somogyi Múzeumok Közleményei 13: 211-215.

KIRÁLY G. (2007): Kiegészítések Külső-Somogy edényes flórájának ismeretéhez. - Somogyi Múzeumok Közleményei 17: 31-40.

KIRÁLY G. (szerk.) (2009): Új magyar füvészkönyv I-II., Magyarország hajtásos növényei, Határozókulcsok-Ábrák. - Aggteleki Nemzeti Park Igazgatóság, Jósvafő.

KovÁcs D. (2014): Adatok Magyarország flórájához I. - Kitaibelia 19: 254-259.

KovÁCS M. \& PRISzTER Sz. (1957): Kiegészítések és adatok „A Magyar Növényvilág Kézikönyvé”-hez. Botanikai Közlemények 47: 87-93.

LÁjER K. (2003): A Látrányi Puszta Természetvédelmi Terület növényzetéről. - Natura Somogyiensis 5: 13-28.

LENGYEL G. (1929): A magyar lucernamag származási vizsgálata. - Kísérletügyi Közlemények 32: 555-622.

MARosi S. \& SOMogy S. (szerk.) (1990): Magyarország kistájainak katasztere I-II. - MTA Földrajztudományi Kutató Intézet, Budapest, 1023 pp.

MÁGocsY-Dietz S. (1914): Adatok a Balaton és környéke flórájának ismeretéhez. - Botanikai Közlemények 13: 117-127.

NAGY T. (2015): Néhány florisztikai adat Kötcse környékéről (Dél-Dunántúl, Nyugat-Külső-Somogy). Kitaibelia 20: 74-80.

Niketić M., Stevanović V. \& Tomović G. (2007): Nomenclatural and taxonomic notes on the flora of Serbia and the Balkan Peninsula, I: Caryophyllaceae. - Archives of Biological Sciences 59: 387-396.

NikLFELD H. (1971): Bericht über die Kartierung der Flora Mitteleuropas. - Taxon 20: 545-571.

Pillich F. (1927): Adatok Tolnamegye flórájához. - Magyar Botanikai Lapok 26: 94-97.

Pinke Gy., PÁl R., KirÁly G. \& SzEndRődi V. (2006): Adatok Külső- és Belső-Somogy gyomflórájának ismeretéhez. - Botanikai Közlemények 93: 53-68.

RoZnER GY., MióKоVICS E. \& VIDÉKI R. (2011): Védett növényfajok előfordulási adatai Észak-Somogyban. Natura Somogyiensis 19: 5-16.

Soó R. \& BoRsos O. (1957): Új adatok a Magyar növényvilág kézikönyvéhez. - Botanikai Közlemények 47: 97.

SzAlóKI I. \& Bódis J. (2004): A Lellei-Bozót és a Szemesi-Berek élőhelyei. - Somogyi Múzeumok Közleményei 16: 279-290.

Z. HoRvÁtH J. (2007): Adatok somogyi tájak flórájához. - Somogyi Múzeumok Közleményei 17: 57-68.

\section{Hivatkozott világháló oldalak}

[1]: http://mlp.archivportal.hu/ (Hozzáférés 2017. 03. 10.)

Beérkezett: 2017. 03.11. • Elfogadva: 2017. 05. 14. 